\title{
Numerical simulations of winter cold damage to citrus fruits using the WRF model
}

\author{
Yukitaka Ohashi ${ }^{1}$ and Hideki Ueyama ${ }^{2}$ \\ ${ }^{1}$ Department of Biosphere-Geosphere Science, Okayama University of Science, Okayama City, \\ Okayama, 700-0005, Japan \\ ${ }^{2}$ Western Region Agricultural Research Center, Zentsuji City, Kagawa, 765-0053, Japan \\ Correspondence: Yukitaka Ohashi (ohashi@big.ous.ac.jp)
}

Received: 3 November 2018 - Revised: 2 February 2019 - Accepted: 4 February 2019 - Published: 13 February 2019

\begin{abstract}
To numerically assess winter cold damages of citrus fruits, a cold duration of sub-zero temperature was simulated using a high resolution configuration (500 m horizontal grid spacing) of the WRF numerical weather prediction system. Japanese citrus is often cultivated on slopes made of a small hill and a valley. Hence, a high resolution spatial configuration is needed to simulate cold durations at complex micro-topographies. In this study, detailed cold duration maps for sub-zero temperatures were produced to assess the spatial difference of cold duration, as an example of a winter cold surge attack in west Japan in 2011. Our findings suggest that the recorded temperature (by automatic observation of the Japan Meteorological Agency), which was observed at a flat coastal plain, may underestimate cold damage risk for citrus fruit on narrow slopes, valleys and hilly areas.
\end{abstract}

\section{Introduction}

In Japan, a strong cold surge (cold air outbreak by a synoptic pressure pattern) in winters has often damaged citrus fruits cultured in outdoor open fields, leading to a reduction in yields (e.g., Nakagawa et al., 1965; Ikeda, 1982; Matsumoto et al., 2018). An example of large-scale cold damage is the economic damage of JPY 750 million (EUR 6.1 million) reported in December 2005 in the west region of Ehime Prefecture which is a major production area of citrus fruits (Ehime Newspaper, 2005). This cold event induced a decrease in the production yield exceeding $6000 \mathrm{t}$. In general, many citrus varieties are known as being vulnerable to sub-zero temperature conditions (e.g., Konakahara, 1984; Jackson, 1992; Inch et al., 2014). The past cold attacks from December to February have caused freeze damage to citrus fruits and physiological disorders of citrus rind, afflicting major Japanese citrus farmers. Figure 1 shows a relationship between yearly yields of lemon (Citrus limon) and "Iyokan" as Japanese name (Citrus iyo) against cold duration defined as integrated hours of sub-zero temperature. The yearly yield data in this figure was provided by the Ministry of Agriculture, Forestry and Fisheries (MAFF) in Japan. As can be seen in this figure, the long exposure of sub-zero temperature decreases citrus yields. Moreover, the global warming progress is likely to lead to a severe cold winter in mid-latitude Eurasian (Mori et al., 2014).

As many citrus orchards are locally spread and scattered on the slope sides of small hills and mountains in Japan, it is difficult to know how cold conditions affect actual orchard fields. The outdoor surface air temperature is continuously observed by the Japan Meteorological Agency (JMA), by their Automated Meteorological Data Acquisition System (AMeDAS). In fact, most AMeDAS observatories that are close to major produce regions of citrus fruits are located at lowland sites near the coast.

A numerical weather prediction (NWP) model has been utilized for the purpose of understanding the spatial distribution of near-surface meteorological elements, such as wind speed, air temperature, and humidity in numerous fields of study as well as agrometeorology. The NWP model output has the potential to evaluate the cold damage risk on complex and micro-scale terrain. Hence, we examine an application of a high-resolution NWP model to quantitatively assess winter cold damages of citrus fruits. 

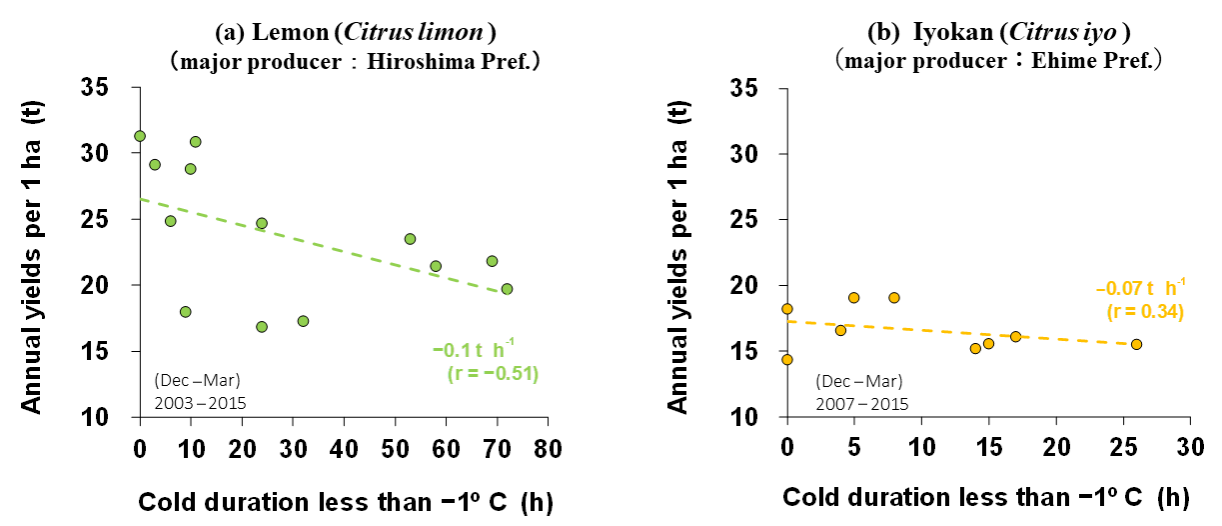

Figure 1. Relationship between the annual cold duration (h) less than $-1{ }^{\circ} \mathrm{C}$ and citrus yield amount (ton per 1 ha) for (a) lemon (2003-2015) and (b) Iyokan (2007-2015).

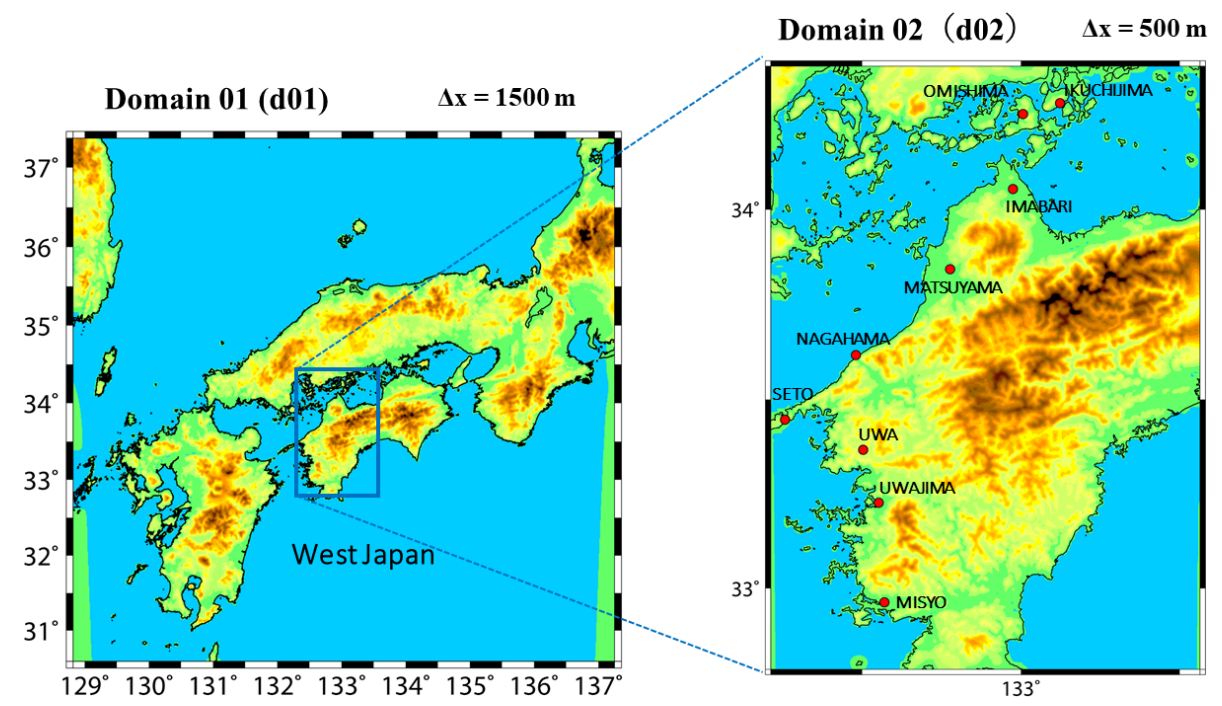

Figure 2. Calculation areas and geographies of coarse resolution (d01) and fine resolution (d02) domains.

\section{Numerical model and calculation settings}

In this study, the Weather Research and Forecasting Model (Ver. 3.8.1 of WRF-ARW; Skamarock et al., 2008) was used to simulate a field exposure of sub-zero temperature. A simulation period from 15 to 16 January 2011, was chosen as an example of strong cold surge. Fruit (mainly citrus) damage amounts of $839 \mathrm{t}(652 \mathrm{ha})$ were reported during the winter of this year in Ehime Prefecture (Official Statics of Japan, 2012). Simulation domains included Ehime Prefecture in the west of Japan at which a citrus cold damage was reported by Ehime Prefecture (2012). A coarse resolution was spatially resolved at $1500 \mathrm{~m}$, while the finer resolution was done at $500 \mathrm{~m}$ (Fig. 2). For a vertical resolution, stretched grids were provided with the lowest height of $22 \mathrm{~m}$ up to $100 \mathrm{hPa}$. Our model settings are summarized in Table 1. An initial time of calculation was set to 09:00 Japan Standard Time (JST) on 14 January 2011 . The outputted data every $10 \mathrm{~min}$ were anal- ysed from 09:00 JST on 15 January to 12:00 JST on 16 January.

Initial and boundary conditions of the model were assigned by the National Centers for Environmental Prediction (NCEP, 2019) final analysis, JMA meso-analysis (JMA, 2019), and UKMO operational sea surface temperature and ice analysis (OSTIA; Donlon et al., 2012) data every $3 \mathrm{~h}$. The land use (100 m resolution) and topographic data $(50 \mathrm{~m}$ resolution) of the Geospatial Information Authority of Japan (GIAJ, 2019) were used in the model. Data assimilation was not carried out in this study.

\section{Results and discussion}

\subsection{Model validation}

Figure 3 shows the simulated and actual observed cold durations between -2 and $-1{ }^{\circ} \mathrm{C}$, those between -3 and $-2{ }^{\circ} \mathrm{C}$, and those less than $-3^{\circ} \mathrm{C}$ at Omishima, Seto, and Misyo sites 
Table 1. Model setting of grids, boundary condition, and physics for $\mathrm{d} 01$ and $\mathrm{d} 02$.

\begin{tabular}{|c|c|c|}
\hline & d01_pbl (Domain 1) & d02_les (Domain 2) \\
\hline Horizontal grids & $1500 \mathrm{~m}$ & $500 \mathrm{~m}$ \\
\hline Vertical grids & \multicolumn{2}{|c|}{$44,67,112,121,153,194 \mathrm{~m} \ldots$} \\
\hline The number of grids & $500($ we $) \times 500($ sn $) \times 34($ vert $)$ & $250($ we $) \times 355(\mathrm{sn}) \times 34($ vert $)$ \\
\hline Initial and boundary conditions & \multicolumn{2}{|c|}{ JMA Meso analysis $(5 \mathrm{~km})$ and UKMO OSTIA SST $\left(0.05^{\circ}\right)$ data } \\
\hline Model top level & \multicolumn{2}{|c|}{$100 \mathrm{hPa}$} \\
\hline Cloud microphysics & \multicolumn{2}{|c|}{ Morrison double-moment (Morrison et al., 2009) } \\
\hline Radiations & \multicolumn{2}{|c|}{$\begin{array}{l}\text { Shortwave Dudhia (1989) } \\
\text { Longwave RRTM (Mlawer et al., 1997) }\end{array}$} \\
\hline Surface layer & \multicolumn{2}{|c|}{ Monin-Obukhov (Janjic Eta) } \\
\hline Land surface process & \multicolumn{2}{|c|}{ Noah LSM } \\
\hline Atmospheric boundary layer & $\begin{array}{l}\text { PBL scheme of } \\
\text { Mellor-Yamada-Nakanishi-Niino } \\
\text { (Nakanishi and Niino, 2009) }\end{array}$ & $\begin{array}{l}\text { Large eddy simulation } \\
\text { (full diffusion) }\end{array}$ \\
\hline Urban canopy & \multicolumn{2}{|c|}{ None } \\
\hline Others & \multicolumn{2}{|c|}{ One-way nesting, slope shadow effect, fog gravitational settling } \\
\hline
\end{tabular}

(a) OMISHIMA

(Lemon and Iyokan)

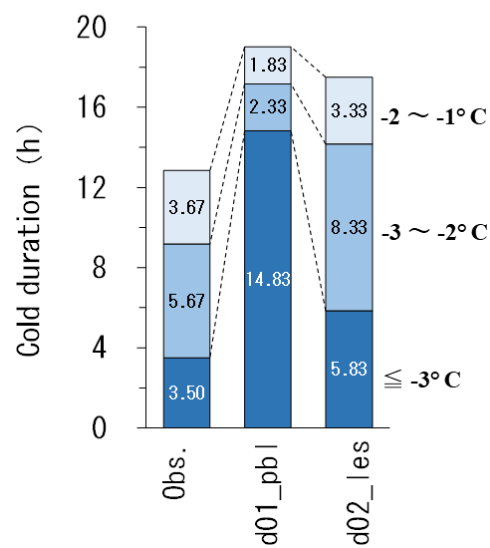

(b) SETO

(Kiyomi) (c) MISYO

(Kawachi-bankan)

Figure 3. Cold durations (h) recorded between -2 and $-1{ }^{\circ} \mathrm{C}$, those between -3 and $-2{ }^{\circ} \mathrm{C}$, and those less than $-3{ }^{\circ} \mathrm{C}$ at (a) Omishima, (b) Seto, and (c) Misyo sites by the AMeDAS observation data, simulated d01, and $\mathrm{d} 02$ results.

(ref., each site location in Fig. 2). This cold duration was integrated during a period of the above-mentioned 09:00 JST on 15 January-12:00 JST on 16 January. The Omishima area has major citrus producers of lemon and Iyokan, while the Seto area has major "Kiyomi" (Citrus unshiu $\times$ sinensis) producers, and the Misyo area has "Kawachi-bankan" in Japanese name (Citrus kawachiensis) producers. Figure 3 indicates the calculation results at model grids, including the AMeDAS observational site in the $\mathrm{d} 01$ and $\mathrm{d} 02$ domains. Omishima (Fig. 3a) altitudes of observational site, d01 grid, and d02 grid are 16, 86, and $15 \mathrm{~m}$ above sea level (a.s.l.), respectively. Seto (Fig. 3b) altitudes of observational site, d01 grid, and d02 grid are 140, 121, and $145 \mathrm{~m}$ a.s.l., respectively. Misyo (Fig. 3c) altitudes of observational site, d01 grid, and d02 grid are 17,27 , and $12 \mathrm{~m}$ a.s.l., respectively. The surface air temperature in the model is a value obtained at a height of $2 \mathrm{~m}$ above ground level (a.g.l.), which is diagnostically estimated from the Bulk parameterisation for surface heat flux. The AMeDAS temperature is also measured at a height of $1.5 \mathrm{~m}$ a.g.l. 
Cold duration less than $-1^{\circ} \mathrm{C}$

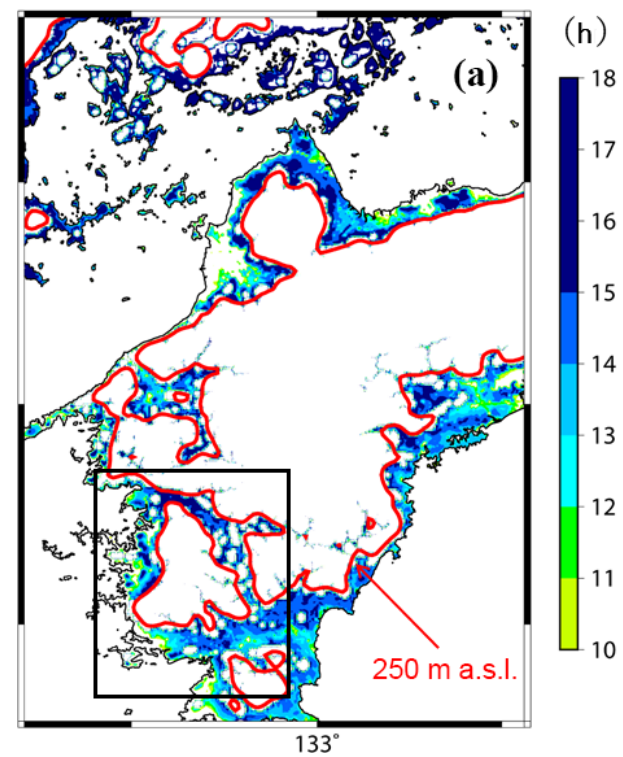

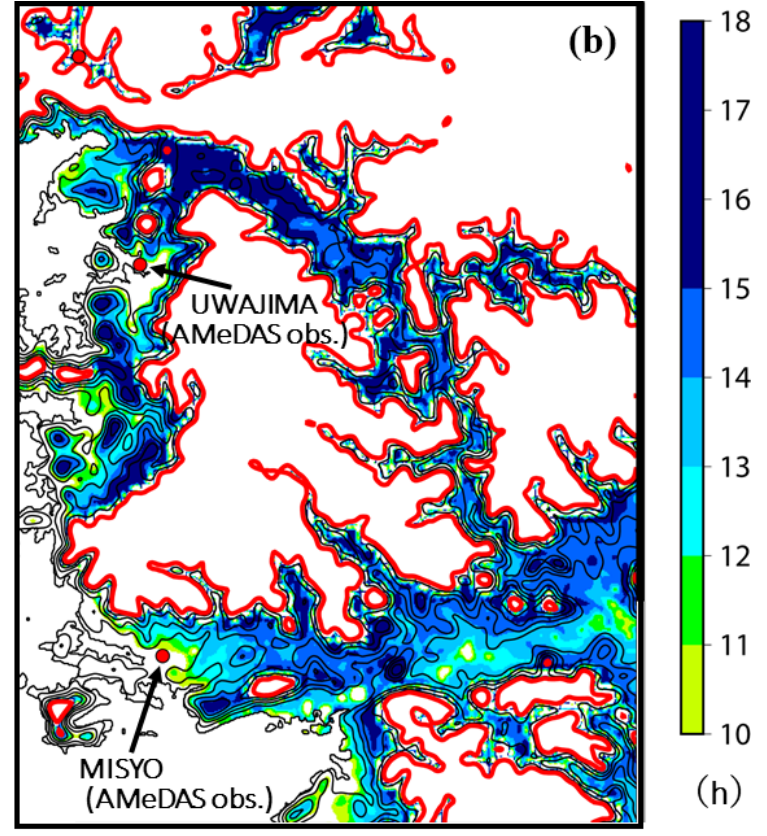

Figure 4. Simulated maps of cold duration (h) less than $-1^{\circ} \mathrm{C}$, which were produced for the (a) d02 entire domain and (b) enlarged rectangle area in the left figure.

At the Seto area (Fig. 3b), the cold duration especially less than $-3{ }^{\circ} \mathrm{C}$ was well reproduced by both $\mathrm{d} 01$ and $\mathrm{d} 02$. Although there seems to be not a large difference between $\mathrm{d} 01$ and $\mathrm{d} 02$ results at Seto and Misyo (Fig. 3c), a cold duration of $\mathrm{d} 02$ at Omishima agreed with the observed that betters than that of d01 (Fig. 3a). This may be because the Omishima site is located at the narrow valley of a small island. In fact, the $\mathrm{d} 01$ grid including the AMeDAS site has a significantly higher altitude than those of the $\mathrm{d} 02$ grid and actual site and includes not only the narrow valley but also the surrounding hills. Therefore, a finer grid setting in the model is required for simulating cold meteorological conditions on complex micro-topographies, which will include narrow slopes, valleys, and hilly areas where citrus fruits are cultivated.

\subsection{Cold duration mapping}

Here, calculated cold duration maps were produced to assess a spatial difference of cold duration less than $-1{ }^{\circ} \mathrm{C}$, using the d02 output data (Fig. 4). As an example, a region including the Misyo site was focused on the right side of Fig. 4. These maps were drawn using the GMT software in which the tone mapping is interpolated by the bicubic method. In these figures, only areas less than $250 \mathrm{~m}$ a.s.l. were visualized because of a cultivate elevation limit of citrus fruits. This was achieved by using a land-use GIS map developed by the Ministry of Land, Infrastructure, Transport and Tourism (MLIT) in Japan. The figure revealed that the cold duration tended to be longer at the foot of mountains, whereas the areas including the AMeDAS observatories of Misyo and Uwajima, which were located on the plain near the coast (as can be seen on the right-side figure), were estimated as having the shortest cold duration. The results suggest that temperatures observed by AMeDAS sites may underestimate the risk of cold damage for citrus fruit from the monitored temperature data.

Figure 5a shows the cold durations simulated at slope grids (A and $\mathrm{B}$ ) in addition to the simulated and observed cold durations at the Misyo site on the plain. The Misyo AMeDAS site is located on at elevation of $12 \mathrm{~m}$ a.s.l., while elevations of $A$ and $B$ are 126 and $83 \mathrm{~m}$ a.s.l., respectively, where citrus cultivation fields spread (Fig. 5b). Simulated cold durations less than $-3{ }^{\circ} \mathrm{C}$ recorded $4.5 \mathrm{~h}$ at both slope grids. This extreme cold condition was not simulated at the AMeDAS grid. A relationship between air temperature observed at Misyo site and the yearly yield of Kawachi-bankan in Ehime Prefecture was analysed in the same manner as Fig. 1. That result showed a yield decrease of $1.5 \mathrm{tha}^{-1}$ for recorded temperatures (at Misyo site) of less than $-2{ }^{\circ} \mathrm{C}$ for $10 \mathrm{~h}$. The cold surge event also observed $5.2 \mathrm{~h}$ of temperatures less than $-2{ }^{\circ} \mathrm{C}$ at the Misyo AMeDAS. In this manner, visualizing a cold temperature by maps provides knowledge of a spatial heterogeneity of cold risk for citrus fruits.

\section{Summary}

In this study, winter cold damage of citrus fruits by cold surge attack was simulated using a high resolution configuration of the WRF NWP model. Japanese citrus is often cultivated on slope lands with a small hill and valley. Here, detail cold du- 


\section{MISYO (Kawachi-bankan)}

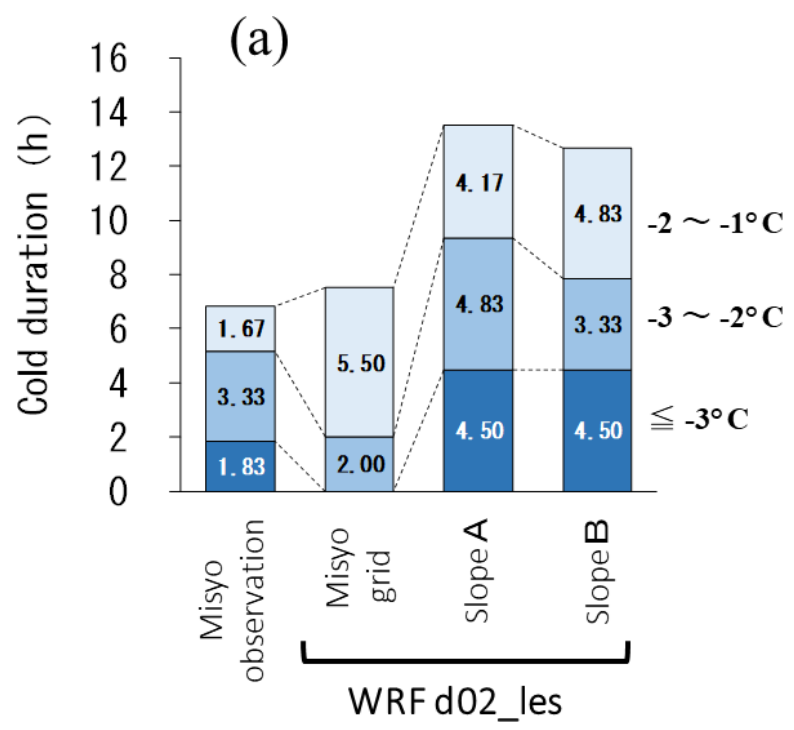

(b)

Simulated cold duration map $\left(<-2^{\circ} \mathrm{C}\right)$

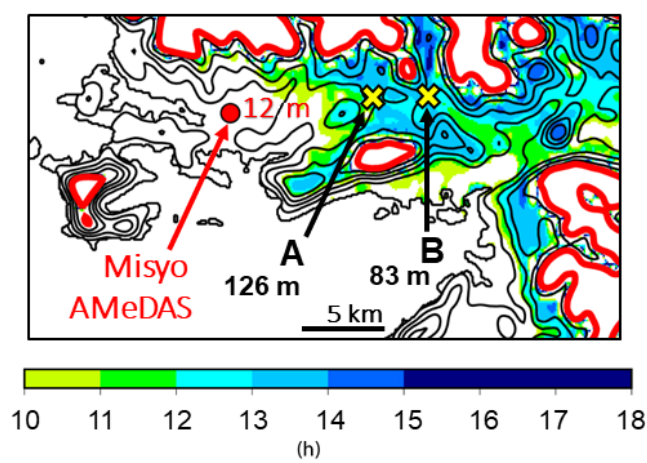

Figure 5. (a) Cold durations (h) observed at the Misyo AMeDAS site and simulated at the grids including the AMeDAS site, slope A, and slope B. (b) Simulated cold duration map (with temperature less than $-2{ }^{\circ} \mathrm{C}$ ) and locations of AMeDAS, slope A, and slope B.

ration maps for sub-zero temperatures were produced to simulate a spatial heterogeneity of cold duration in west Japan during the winter of 2011. The simulation results demonstrated that the temperature measured at AMeDAS sites at coastal locations underestimated the risk of cold damage for cultivated citrus fruits on narrow slopes, valleys, and hilly areas. This fact suggests a necessity for a numerical meteorological model for predicting cold damage, which can resolve complex micro-topographies where citrus fruits are cultivated. A higher resolution configuration such as of 100$200 \mathrm{~m}$ may improve the accuracy of the sub-zero temperature maps further.

Data availability. Data are available via e-mail request to the corresponding author.

Author contributions. HU provided the idea and motivation of this study and YO carried it out. YO performed the simulations and prepared the manuscript.

Competing interests. The authors declare that they have no conflict of interest.

Special issue statement. This article is part of the special issue "18th EMS Annual Meeting: European Conference for Applied Meteorology and Climatology 2018”. It is a result of the EMS Annual Meeting: European Conference for Applied Meteorology and Climatology 2018, Budapest, Hungary, 3-7 September 2018.
Acknowledgements. Input data of the WRF was arranged and provided by Teruo Osawa in Kobe University, Japan. This study was supported by JSPS KAKENHI Grant-in Aid for Scientific Research (C) number 16K07963. The Generic Mapping Tools (GMT) graphics system (Wessel and Smith, 1998) was used for drawing some figures.

Edited by: Keith Lambkin

Reviewed by: two anonymous referees

\section{References}

Dudhia, J.: Numerical study of convection observed during the winter monsoon experiment using a mesoscale two-dimensional model, J. Atmos. Sci., 46, 3077-3107, 1989.

Donlon, C. J., Martin, M., Stark, J. D., Roberts-Jones, J., Fiedler, E., and Wimmer, W.: The operational sea surface temperature and sea ice analysis (OSTIA) system, Remote Sens. Environ., 116, 140-158, 2012.

Ehime Newspaper: Ehime Newspaper Database, available at: http:// www.ehime-np.co.jp/pr/db/ (last access: 3 January 2019), article in 2005.

Ehime Prefecture: Kankitsu-kajitsu no Kangai to Shizai niyoru Kangai-boushi-kouka, Hukyu dayori, 1, 5-5, available at: https://www.pref.ehime.jp/nan99909/seiyo/documents/ hp23fukyuudayori_1.pdf (last access: 3 January 2019), 2012 (in Japanese).

GIAJ (Geospatial Information Authority of Japan): National Land Numerical Information download service, available at: http:// nlftp.mlit.go.jp/ksj-e/index.html, last access: 3 January 2019.

Ikeda, I.: Freeze injury and protection of citrus in Japan, Plant cold hardiness and freezing stress: mechanisms and crop implications, Academic Press, Inc., New York, 575-590, 1982. 
Inch, S., Stover, E., Driggers, R., and Lee, R.: Freeze response of citrus and citrus-related genotypes in a Florida field planting, HortScience, 49, 1010-1016, 2014.

Jackson, L. K.: Cold damage symptoms on citrus, University of Florida Institutional Repository, available at: http://ufdc.ufl.edu/ IR00004614/00001 (last access: 3 January 2019), 1992.

JMA (Japan Meteorological Agency) meso analysis: Joint WMO technical progress report on the global data processing and forecasting system and numerical weather prediction research activities for 2017, available at: http://www.jma.go.jp/jma/jma-eng/ jma-center/nwp/report/2017_Japan.pdf, last access: 3 January 2019.

Konakahara, M.: Cold injuries on citrus trees and the practical management for their protection, J. Agr. Met., 39, 315-322, 1984 (in Japanese).

Matsumoto, K., Okumura, R., Shinomiya, R., and Muramoto, K.: Differences in Freezing Resistance of Citrus Varieties in Nursery Stocks based on Data Obtained during a Cold Snap in 2016, Bull. Fukuoka Agric. Res. Cent., 4, 122-128, 2018.

Mlawer, E. J., Taubman S. J., Brown, P. D., Iacono, M. J., and Clough, S. A.: Radiative transfer for inhomogeneous atmosphere: RRTM, a validated correlated-k model for the longwave, J. Geophys. Res., 102, 16663-16682, 1997.

Mori, M., Watanabe, M., Shiogama, H., Inoue, J., and Kimoto, M.: Robust Arctic sea-ice influence on the frequent Eurasian cold winters in past decades, Nat. Geosci., 7, 869-873, 2014.

Morrison, H., Thompson, G., and Tatarskii, V.: Impact of cloud microphysics on the development of trailing stratiform precipitation in a simulated squall line: comparison of one and two-moment schemes, Mon. Weather Rev., 137, 991-1006, 2009.
Nakagawa, Y., Konakahara, M., and Sumida, A.: Studies on the climatically favourable place for fruit culture (2) Responses of fruits to freezing temperature in Citrus natsudaidai, J. Agr. Met., 21, 47-52, 1965.

Nakanishi, M. and Niino, H.: Development of an improved turbulence closure model for the atmospheric boundary layer, J. Meteorol. Soc. Jpn, 87, 895-912, 2009.

NCEP (National Centers for Environmental Prediction/National Weather Service/NOAA/U.S. Department of Commerce): NCEP FNL Operational Model Global Tropospheric Analyses, continuing from July 1999, Research Data Archive at the National Center for Atmospheric Research, Computational and Information Systems Laboratory, https://doi.org/10.5065/D6M043C6, last access: 3 January 2019.

Official Statics of Japan (e-Stat): Statistics of Japan, available at: https://www.e-stat.go.jp/ (last access: 3 January 2019), 2012.

Skamarock, W. C., Klemp, J. B., Dudhia, J., Gill, D. O., Barker, D. M., Duda, M. G., Huang, X.-Y., Wang, W., and Powers, J. G.: A description of the advanced research WRF version 3, NCAR Tech. Note NCAR/TN-475+STR, 113 pp., 2008.

Wessel, P. and Smith, W. H. F.: New, improved version of the generic mapping tools released, EOS T. Am. Geophys. Un., 79, p. $579,1998$. 